\title{
Technical Efficiency Analysis of Sugar Cane Production in East Java
}

\author{
Wiwit Widyawati* \\ Department of Socio Economics, Faculty of Agriculture, Brawijaya University, Jl. Veteran, Malang \\ 65145, Indonesia \\ Received: 13 January 2020; Revised: 19 May 2020; Accepted: 11 June 2020
}

\begin{abstract}
Having an important role as the main supplier of sugar cane in Indonesia that processed into sugar, so that East Java as a producer of sugar cane both with Ratoon Cane (RC) and Plant Cane (PC) must be supported by the government to be more productive and competitive. One of them is through increasing sugar cane yield through increasing technical efficiency. The purpose of this study is to analyze the level of technical efficiency in the use of sugar cane farming and identify the level of technical efficiency of farm households. The research location was determined purposively in Malang, Pasuruan, Lumajang, Bondowoso and Situbondo Regencies in July - December in 2018. Determination of respondents was carried out using the typical case sampling method. The technical efficiency of each farmer is carried out using a comparison of the actual production functions achieved by farmers using the frontier production function. The results showed the level of technical efficiency in sugar cane farming in wetland and dry land using RC and PC planting systems respectively averaged $89.44 \%$ and $99.80 \%$ so it was technically efficient.
\end{abstract}

Keywords: ratoon; plant cane; technical efficiency

How to Cite:

Widyawati, W. (2020). Technical Efficiency Analysis of Sugar Cane Production in East Java. HABITAT, 31(2), 95-101. https://doi.org/10.21776/ub.habitat.2020.031.2.11

\section{Introduction}

Based on data from the Directorate General of Plantations in 2017, East Java was the largest sugar cane producing Province for the last 3 years in 2015-2017 with an average of 1.02 million tons per year. The East Java's contribution to the national sugar cane production is $74.19 \%$ per year. This production was spread in almost all regencies/cities in East Java Province, including Malang, Pasuruan, Lumajang, Situbondo and Bondowoso Regencies.

The rate of sugar cane productivity growth in the Province of East Java over the past 3 years has a positive trend which increased by $11.4 \%$ in 2017. It's higher than in Java and Indonesia, which was $9.05 \%$ and $8.97 \%$. One of the improvements in productivity is supported by an increase in harvested area. Where during the last 3 years the growth of sugar cane harvested area in East Java and Indonesia tended to increase

*Correspondence Author

E-mail : wiwit23@ub.ac.id
$1.15 \%$ and $1.78 \%$ in 2017 (Directorate General of Plantations, 2017).

The types of land to cultivate sugar cane in East Java are divided into 2, there are wetland and dry land. The cultivation technique that used by farmers in East Java is the same as the technique for sugar cane cultivation in general farmers, namely Plant Cane (PC) and Ratoon Cane (RC) techniques. In this regard, the almost all farmers in East Java do not have the option to choose the type of land that they are going to cultivate.

Land availability and suitability are important in relation to the role of East Java province as the main supplier of sugar cane for further processing into sugar in Indonesia. Therefore, sugar cane production must be supported by the government to be more productive and competitive. This can be achieved one of them through increasing the sugar cane production in the management of existing resources and technology. In this regard, it is necessary to identify the opportunities to increase sugar cane productivity through increasing technical efficiency, both the technical efficiency 
of sugar cane in wetland and dry land.

Based on the background and the problems faced, it can be formulated that the problem will be analyzed in this study is what is the level of technical efficiency of the use of production factors in sugar cane farming.

\section{Research Method}

The research location was determined purposively in 5 districts in East Java: Malang, Pasuruan, Lumajang, Bondowoso and Situbondo Regencies. The study was conducted in July to December in 2017 with the consideration that the research location is the central location of $\mathrm{PG}$ and sugar cane commodity. Data collection method was done by using the interview (indepth interview). Determination of respondent was carried out using a typical case sampling method based on the general characteristics of the sugar cane farmers population that was already known (Dwiastuti, 2017).

\subsection{The Method of Technical Efficiency Analysis of Sugar Cane Farmers}

The calculation of the technical efficiency value of each farmer used with a comparison of the actual production function achieved by farmers using a potential/frontier production function (Coelli, Rao, O'Donnel, and Battese, $2005)$ with the MLE method.

$\operatorname{Ln} Y_{\mathrm{i}}=\operatorname{Ln} \beta_{0 \mathrm{i}}+\beta_{1 \mathrm{i}} \operatorname{LnX} X_{1 \mathrm{i}}+\beta_{2 \mathrm{i}} \operatorname{Ln} X_{2 \mathrm{i}}+\beta_{3 \mathrm{i}} \operatorname{LnX} X_{3 \mathrm{i}}+$ $\beta_{4 i} \operatorname{Ln} X_{4 i}+\beta_{5 i} \operatorname{LnX} X_{5 i}+\beta_{6 i} \operatorname{LnX} X_{6 i}+\beta_{7 i} \operatorname{LnX}_{7 i}+$ $\beta_{8 \mathrm{i}} \operatorname{Ln} \mathrm{X}_{8 \mathrm{i}}$ (vi - ui)

$\mathrm{Y}=$ the amount of sugar cane production (ton)

$\beta 0=$ constant or intercept

$\beta \mathrm{i}=$ estimated parameters

$\mathrm{X} 1=$ seeds $(\mathrm{kg})$

$\mathrm{X} 2=\mathrm{NPK}$ fertilizer $(\mathrm{kg})$

$\mathrm{X} 3=\mathrm{ZA}$ fertilizer $(\mathrm{kg})$

$\mathrm{X} 4=$ urea fertilizer $(\mathrm{kg})$

$\mathrm{X} 5=$ SP36 fertilizer $(\mathrm{kg})$

$\mathrm{X} 6=$ compost $(\mathrm{kg})$

$\mathrm{X} 7=$ Herbicides (liter)

$\mathrm{X} 8$ = labour (man days)

$\mathrm{i}=$ farmeri-i, $\mathrm{i}=1,2, \ldots, \mathrm{n}$

$\mathrm{g}=$ error term from farmer-i, $\mathrm{g}=\mathrm{vi}-\mathrm{ui}$

$\mathrm{vi}=$ stochastic error term

$\mathrm{ui}=$ technical inefficiency effects

The mathematical equation of farmer technical efficiency values can be written in equation 2 below:

$\mathrm{TEi}=\frac{\mathrm{Yi}}{\operatorname{Exp}(\alpha \mathrm{Xij})}=\frac{\sum_{\mathrm{j}=1}^{6} \exp (\alpha \mathrm{ij}-\mathrm{Uij})}{\sum_{\mathrm{j}=1}^{6} \exp (\alpha \mathrm{Xij})}=$ $\exp (-\mathrm{Uij})$

Where :

$\mathrm{TEi}=$ technical efficiensy-i

Yi = the amount of sugar cane production by farmer-i (ton)

$\mathrm{Xi}=$ the amount of input usage by farmeri(seeds (kg), NPK (kg), ZA (kg), Urea $(\mathrm{kg})$, SP36 (kg), compost (kg), Herbicides (liter), labour (man days))

$\alpha \quad=$ estimated parameters

$\mathrm{Uij}=$ random variable associated with the technical efficiency

$\mathrm{i} \quad=$ farmer-i, $\mathrm{i}=1,2,3, \ldots \ldots, \mathrm{n}$

$\mathrm{j} \quad=$ farmer input- $\mathrm{j}, \mathrm{j}=1,2,3, \ldots . ., \mathrm{n}$

Based on the equation above, it is known that the value of technical efficiency (TE) ranges from 0 to $1(0<\mathrm{TE}=1)$. If the TE value is close to 1 then farming is said to be more efficient, but TE is close to 0 , then farming is said to be more inefficient (technically inefficient).

The hypothesis that sugar cane farming in Malang, Pasuruan, Lumajang, Bondowoso and Situbondo districts has not yet reached technical efficiency is shown as follows:

$\mathrm{H} 0: \sigma u^{2}=0$, which means that there is no technical efficiency effects in the model.

$\mathrm{H} 1: \sigma \mathrm{u}^{2}>0$ which means that there is technical efficiency effects in the model.

This hypothesis stated that $S_{\mathrm{v}}^{2}=0$ it means $\mathrm{g} \frac{\mathrm{Su}}{\mathrm{Sv}}$ Hypothesis testing is done using a Likelihood Ratio test that generalized to decide whether to accept or reject the hypothesis (Asmara, 2016). The LR test formula in equation 3 as follows:

$\mathrm{LR}=-2[\ln (\mathrm{Lr})-\ln (\mathrm{Lu})]$

Where :

LR = Likelihood Ratio

$\mathrm{Lr} \quad=\mathrm{LR}$ value OLS approach

$\mathrm{Lu} \quad=\mathrm{LR}$ value MLE approach

Than LR value will compare with critical value $\chi 2$ (Kodde dan Palm, 1986).

LR one side error $=\chi^{2}($ Kodde dan Palm) reject H0

LR one side error $>\chi^{2}$ (Kodde dan Palm) accept H1

According to Asmara (2011), the null hypothesis states that there is no inefficient effect on the variance of confounding errors and hypothesis one means there is an inefficient effect on the variance of confounding errors. 


\section{Result and Discussion}

a. Cultivation Technique of Ratoon Cane in Dry land

Ratoon Cane (RC) is a sugar cane plant that grows after the first planting is by cutting most of the above-ground portion but leaving the roots and the growing shoot apices intact so as to allow the plants to recover and produce a fresh crop in the next season. Rationing is cutting down sugar cane stems to a depth of $20 \mathrm{~cm}$ from ground using a hoe and make the soil like a bed so sugar cane that will grow is expected to still have a same quality from the sugar cane plants.

The good quality of sugar cane is seen from the value of the sugar cane yield. After one month, sugar cane plants will grow some shoots and then cut down the root of the sugar cane. It is the activities for cutting down the roots to stimulate the growth of new roots. The range of it is about $15 \mathrm{~cm}$ from the sugar cane. The next activity is sugar cane maintenance which includes weeding, replanting, fertilizing, planting and stripping, as in sugar cane plant cane.

b. Harvest and Post Harvest

Logging and transporting in the area of the Kebon Agung, Kedawoeng, Djatiroto, Pradjekan and Wringinom Sugar Factory can be done by farmers and factories. Logging and transporting activities were conducted by themselves. This is because the majority of farmers have no capital can borrow to the factory to carry out logging and transporting. Determination of the logging schedule is done according to the level of sugar cane maturity, based on the results of the previous taxation. Taxation is carried out by the factory twice a year, it is in March and December, where December is carried out for the preparation of the next milling and March is time to prepare planting, milling and estimated yield of sugar cane schedule. Sugar factories determine the level of maturity of sugar cane based on the results of sampling from sugar cane to see whether sugar cane has a yield of about six to seven percent. The sugar cane that will be ground must be sweet, clean and fresh. The sweetness of it is determined from the sample of sugar cane, it cleanness is seen from the percentage of dirt that will be ground and the freshness is seen from the condition of sugar cane when it is to be ground. This means that when logging, loading and transporting, sugar cane that has been cut down is directly transported to sugar factory for the milling process and sugar cane that has been cut down is not placed outside more than 24 hours. This is done so that the yield of sugar cane does not go down.

c. Production-sharing system

The production sharing system between farmers and sugar factory is about 66 percent for farmers from the sugar produced and 34 percent for the sugar factory produced. The the sugar cane yield affects the sugar production that will be produced. The greater yield of sugar cane so farmers have a great sugar too. Farmers also get money from molasses produced from sugar cane processing whose value is determined by the factory according to the quality of the sugar cane.

\section{d. Sugar Cane Yield}

Sugar cane yield is the percentage of sugar content in sugar cane. It greatly affects the production of sugar that produced. The greater the yield of sugar cane, the greater the production of sugar can be produced. The average yield of sugar cane that obtained by farmers when using Ratoon Cane (RC) and Plant Cane (PC) in 2016/2017 was 7,07 and 7,22 percent. The yield of sugar cane farming using PC is $0,15 \%$ higher than using $\mathrm{RC}$ technique. (Detailed data is presented in Table 1).

Table 1. Sugar cane Yield in Wetland and Dry Land RC and PC

\begin{tabular}{cccc}
\hline Planting & \multicolumn{3}{c}{ Sugar cane Yield } \\
\cline { 2 - 4 } System & MIN & MAX & Average \\
\hline RC & 5.90 & 8.01 & 7.07 \\
PC & 6.20 & 7.76 & 7.22 \\
\hline
\end{tabular}

3.1. Analysis of the Level of Technical Efficiency in the Use of Sugar Cane Production Factors

Technical efficiency is a measurement that compares outputs and inputs, or the amount of output that produced from an allocation number of input used. Efficiency shows the ratio between output and input associated with the achievement of maximum output with a certain number of inputs, this can be seen from the greater ratio of output and input, the efficiency is said to be higher. 
The results of the study using the stochastic frontier shows that the distribution of technical efficiency levels achieved by farmers in wetland and dry land using RC has the highest level of technical efficiency of 0.95822 and the lowest value of technical efficiency of 0.75478 . The results of the distribution of the level of technical efficiency of farmers in wetland and dry land using RC is more than $80 \%$ of farmers reach technical efficiency values of around 0.85651 to 0.95822 while the remaining 11.11 percent reach technical efficiency levels of around 0.75478 to with 0.85650 (detailed data are presented in Figure 1).

Technical efficiency is related to the combination of the use of production inputs to get a maximum production level of sugar cane. The results of estimating parameters of the stochastic frontier production function of sugar cane in wetland and dry land using RC are presented in Table 2.

Table 2. Estimation Results of the Stochastic Frontier Production Function of RC Wetland and dry land

\begin{tabular}{cccc}
\hline Variable & Coefficient & $\begin{array}{c}\text { Std. } \\
\text { Eror }\end{array}$ & $\mathbf{P}>|\mathbf{z}|$ \\
\hline Seeds & -0.0062 & 0.0188 & 0.743 \\
NPK & 0.0098 & 0.0155 & 0.526 \\
ZA & -0.0050 & 0.0154 & 0.744 \\
Urea & 0.0057 & 0.0309 & 0.852 \\
SP36 & 0.0408 & 0.0341 & 0.231 \\
Compost & 0.0016 & 0.0516 & 0.975 \\
Herbicides & -0.0197 & 0.0609 & 0.745 \\
Labour & 0.368 & 0.1349 & 0.006 \\
Constant & 2.868 & 0.6574 & 0.000 \\
Sigma v & 0.148 & 0.0404 & \\
Sigma u & 0.145 & 0.1125 & \\
Sigma2 & 0.043 & 0.0227 & \\
Gamma & 0.0499 & & \\
\hline
\end{tabular}

The gamma parameter value $(\gamma)$ of 0.0499 indicates that the variation of the confounding error in the model due to technical inefficiency (ui) was 4.990 percent. This shows that the difference between actual production and the possibility of maximum production is more due to differences in technical inefficiencies.

The technical inefficiency index shows the level of technical efficiency achieved by each farmer in wetland and dry land using RC while carrying out farming activities in a certain period. Based on Figure 1 the results showed that the minimum level of technical efficiency was 0.75478 , a maximum of 0.95823 and an average of 0.89438 .

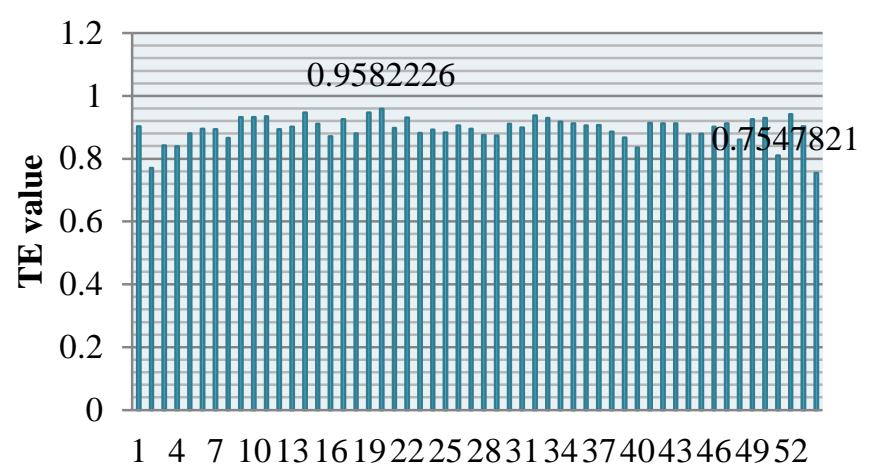

Number of Responden

Figure 1. Distribution of Technical Efficiency Levels on Wetland and Dry Land Using RC

The average level of technical efficiency achieved by farmers in wetland and dry land using $\mathrm{RC}$ is 0.89438 . This shows that farmers have reached a technically efficient level. The average value of technical efficiency shows that overall the average productivity achieved by farmer reaches 89.438 percent of the frontier, that is the maximum productivity that can be achieved. In addition, it shows that farmers in wetland and dry land using RC on average reach an actual condition of 89.438 percent and require an increase of 10.562 percent to reach potential conditions.

Variables that need to be considered to achieve potential production include allocating the amount of input that used in accordance with the needs of plants and land. The input variables that need to be reduced among others varabel number of seeds, ZA fertilizer, and the amount of herbicide. This is evidenced by the results of frontier calculations which show that the coefficient value of the number of seeds, the amount of ZA fertilizer and the amount of herbicide is negative. This means that the addition of them does not cause an increase in sugar cane production. Addition of seed inputs, ZA fertilizer and herbicides causes a decrease in sugar cane production. In addition, the potential production conditions not yet achieved in sugar cane production in wetland and dry land can be caused by the use of several inefficient production factors such as seed production factors, limited information about the actual land conditions related to fertilizer and herbicide needs on the land and the conditions of limited capital.

While the variables that need to be added to achieve the potential production of sugar cane 
are the amount of compost and labor in several types of work such as labor in preparation for planting, planting, kepras, heap, strip and harvest. This is evidenced by the results of research showed that the variable coefficient of the amount of compost and labor is positive, which means that if the input is added to its use it will cause an increase in sugar cane production.

In addition to the amount of compost and labor that need to be added, other variables that show positive effects but not statistically significant are the variables of NPK fertilizer, Urea fertilizer and SP36 fertilizer. This indicates that there needs to be an analysis of fertilizer requirements on the sugar cane farms of farmers both wetland and dry land. This is needed to determine the composition of fertilizer requirements that needed by the land in the current actual conditions. Therefore, the allocation of the use of NPK, ZA, urea, SP36 fertilizer needs to be analyzed in each field.

The distribution of the level of technical efficiency of sugar cane farmers in wetland and dry land using PC planting system are presented in Figure 2.

The results using the stochastic frontier showed that the distribution level of technical efficiency achieved by farmers in wetland and dry land using PC had the highest level of technical efficiency of 0.998093 and the lowest value of technical efficiency of 0.998007 And there are $64 \%$ of farmers achieving technical efficiency values of around 0.998007 to 0.998050 while the remaining $36.00 \%$ percent reaches the level of technical efficiency around 0.99806 up to 0.998093 (detailed data are presented in Figure 2).

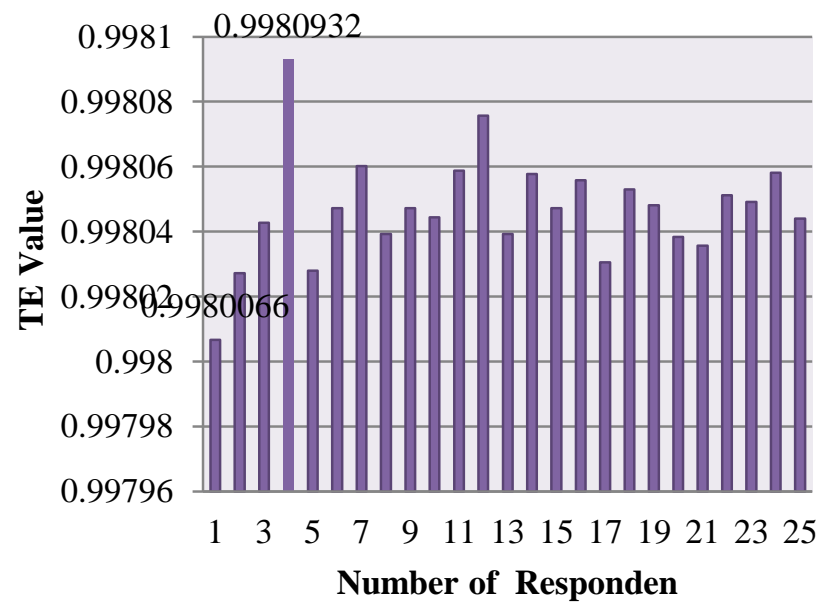

Figure 2. Distribution of Technical Efficiency Levels Each Farmers on Wetland and Dry Land using PC
The technical inefficiency index shows the level of technical efficiency achieved by each farmer in wetland and dry land using PC in carrying out farming activities in a certain period. Based on Figure 2, the results shows that the minimum level of technical efficiency is 0.998007 , the maximum is 0.998093 and on average 0.9980471 .

The estimation results of parameters to test the hypothesis and technical efficiency index of sugar cane in wetland and dry land using PC planting system are presented in Table 2 .

The value of gamma parameter $(\gamma)$ of 0.0034 indicates that the variation of the confounding error in the model due to technical inefficiency (ui) was 0.34 percent. This shows that the difference between actual production and the possibility of maximum production is more due to differences in technical inefficiencies.

The average level of technical efficiency that achieved by farmers in wetland and dry land using PC planting system is 0.9980471. This shows that farmers have reached a technically efficient level but have not yet reached the full efficient condition. The average value of technical efficiency shows that overall the average productivity achieved by sugar cane farming reaches 99.80471 percent of the frontier, that is the maximum productivity that can be achieved with the farming processing system that has been done. In addition, this shows that farmer reach an actual condition on average of 99.80471 percent and require an increase of 0.1953 percent to reach a potential condition.

Table 3. Estimation Results of the Stochastic Frontier Production Function of Sugar Cane using PC on Wetland and Dry Land

\begin{tabular}{cccc}
\hline Variable & Coefficient & Std. Eror & $\mathbf{P}>|\mathbf{z}|$ \\
\hline Seeds & -0.1701 & 0.0982 & 0.083 \\
NPK & -0.0166 & 0.0169 & 0.327 \\
ZA & 0.0045 & 0.0171 & 0.789 \\
Urea & -0.0035 & 0.0439 & 0.935 \\
SP36 & 0.0101 & 0.0479 & 0.835 \\
Compost & -0.0619 & 0.0350 & 0.077 \\
Herbicides & 0.0196 & 0.0742 & 0.791 \\
Labour & 0.5251 & 0.1536 & 0.001 \\
Constant & 2.8982 & 1.0249 & 0.005 \\
Sigma v & 0.1331 & 0.0189 & \\
Sigma u & 0.0025 & 0.2693 & \\
Sigma2 & 0.0177 & 0.0051 & \\
Gamma & 0.0034 & & \\
\hline
\end{tabular}


Variables that need to be considered to achieve potential production conditions include allocating the amount of input used in accordance with the needs of plants and land. input variables that need to be reduced are number of seeds, NPK fertilizer, SP36 fertilizer and Urea fertilizer. This is showed by the results of the frontier calculation which shows that the coefficient value of the number of seeds, the amount of NPK fertilizer, SP36 fertilizer and urea is negative. This means that the addition of seed, NPK fertilizer, SP36 fertilizer and Urea does not cause an increase in sugar cane production but what happens is the opposite. Addition of seed, NPK fertilizer, SP36 fertilizer and Urea cause a decrease in sugar cane production. In addition, the reason why the potential production conditions still have not yet been achieved by farmers is condition of limited capital and limited information about the actual land conditions related to fertilizer requirements needed on the land.

While the variables that need to be in order to achieve the potential production of sugar cane are the number of herbicides and labor. This is showed by the variable coefficient of ZA fertilizer, $\mathrm{KCl}$ fertilizer, herbicide, and labor is positive, which means that if the input is added, it will cause an increase in sugar cane production (detailed analysis results are presented in Table $3)$.

Another variable that shows a positive effect but not statistically significant based on frontier is the variable of $\mathrm{ZA}$ fertilizer and $\mathrm{KCl}$ fertilizer. This indicates that there needs to be an analysis of fertilizer requirements on the sugar cane farms of farmers both wetland and dry land. This is needed to determine the composition of fertilizer requirements needed by the land in the current actual conditions. Therefore, the allocation of the use of NPK, ZA, urea, SP36, $\mathrm{KCl}$ fertilizer needs to be analyzed the fertilizer requirements in each land.

e. Comparison of Technical Efficiency Value of Sugar Cane Farming on Wetland and Dry Land Using RC and PC Planting System

Based on Table 4, it is known that the technical efficiency of sugar cane farming in wetland and dry land using RC and PC planting system shows a slight difference. It is known that sugar cane farming in wetland and dry land using a PC planting system has a higher technical efficiency value than using RC planting systems.
Table 4. Comparison of the Technical Efficiency Value of Sugar Cane Farming on Wetland and Dry Land Using RC and PC Planting System

\begin{tabular}{|c|c|c|c|}
\hline \multirow{2}{*}{$\begin{array}{l}\text { Planting } \\
\text { System }\end{array}$} & \multicolumn{2}{|c|}{$\begin{array}{c}\text { Technical Efficiency } \\
\text { Level }\end{array}$} & \multirow[t]{2}{*}{ Average } \\
\hline & MIN & MAX & \\
\hline $\mathrm{RC}$ & 0.7547821 & 0.9582226 & 0.8943841 \\
\hline PC & 0.9980066 & 0.9980932 & 0.9980471 \\
\hline
\end{tabular}
efficiency of sugar cane farming in wetland and dry land using RC and PC planting systems is 0.103663 or the technical efficiency value is higher by $10.38658 \%$ compared to the technical efficiency level using RC planting system.

The results of this study are the same as the results of Kartika and Wibowo's research in 2019 which stated that the average technical efficiency value of PC sugar cane farming was higher (0.93) than the average technical efficiency value of RC sugar cane farming which was 0.89 . This is because the PC sugar cane farming has a higher productivity which ranges from 70 tons to 150 tons per Ha. while the RC sugar cane is capable of producing productivity around 50-130 Ton / Ha.

\section{Conclusions}

The level of technical efficiency of the use of production factors in sugar cane farming in wetland and dry land that use RC and PC planting systems on average reaches $89.44 \%$ and $99.80 \%$ so that it is categorized technically efficient and each sugar cane farming who use $\mathrm{RC}$ and PC planting systems on wetland and dry land still have $10.56 \%$ and $0.20 \%$ opportunities respectively to reach the potential production level and reach full efficient conditions.

It is necessary to increase farmers' knowledge through one of them is more agricultural extension related to sugar cane cultivation techniques that pay attention to the conditions of land suitability so that their knowledge will increase and can follow the up to date information all about sugar cane cultivation. So that, farmers can allocate production factors according to their individual needs land type and there is no use of production inputs that don't need to add in sugar cane farming, such as the use of fertilizers which causes a decrease in sugar cane production because the fertilizer allocation is not in accordance with the technical recommendations of cultivation and land suitability conditions. 


\section{References}

Asmara, Rosihan. 2017. Efisiensi Teknis Usahatani Tanaman Pangan Dalam Upaya Peningkatan Produksi: Pendekatan Fungsi Frontir Stokastik dan DEA. Malang: Universitas Brawijaya.

Beattie, Bruce R., and C. Robert Taylor. 1985. The Economics of Production. New York: John Wiley \& Sons.

Coeli, T., Rao, D. S. P., \& Battase, G. E. 2005. An Introduction to Efficiency and Productivity Analysis. Kluwer Academic Publisher, London.

Debertin, David L. 1986. Agricultural Production Economics. New York: Macmillan Co.

Debertin, David L. 2010. Agricultural Production Economics Bibliography:p 1. Agricultural production economics.

Doll, John P., and Frank Orazem. 1984. Production Economics, Theory with Applications, 2nd ed. New York: John Wiley \& Sons.

Dwiastuti, Rini. 2017. Metode Penelitian : Sosial Ekonomi Pertanian. UB Press. Malang.

Farrell, M. J. 1957. 'The measurement of productive efficiency', Journal of the Royal Statistical Society.

Kartika, Intan dan Wibowo, Rudi. 2019. Efisiensi Teknis Produksi Usahatani Tebu Plant Cane dan Tebu Ratoon Cane (Studi Kasus di PT. Perkebunan Nusantara X). JSEP Vol 12 No 1 Maret 2019.

Kumbhakar, C. S. 2002. Spesification and Estimation of Production Risk, Risk Preferences and Technical Efficiency. American Journal of Agricultural Economies, 84 (1) : 8-22.

Pusdatin. 2016. Outlook Tebu. Jakarta: Pusat Data dan Sistem Informasi Pertanian. Kementerian Pertanian.

Soekartawi. 1990. Teori Ekonomi Produksi dengan Pokok Pembahasan Analisis Faktor Produksi Cobb Douglas. Jakarta : Rajawali Pres.

Soekartawi. 2005. Analisis Usahatani. UI Press. Jakarta. Soekartawi. 2003. Agribisnis Teori dan Aplikasi.PT. Raja Grafindo Persada. Jakarta.
Sumodiningrat, G. 1996. Ekonometrika Pengantar. Yogyakarta: BPFE. 